\title{
Innovation as a Critical Success Factor: an Exploratory Study about the Partnership among University with Pharmaceutical Industry in Brazil
}

\author{
Michele de Medeiros Rocha', Gilson Brito Alves Lima², Valdir de Jesus Lameira ${ }^{3}$, \\ Osvaldo Luiz Gonçalves Quelhas ${ }^{4}$
}

\begin{abstract}
Interaction between universities and companies is common in Countries considered to be developed and innovative. In Brazil, this strategy is not widely used, although some relevant actions have produced good results in the pharmaceutical sector. The Brazilian Innovation Law, which is considered a milestone, created the Technology Innovation Centers (TICs) in universities, and is seen by the Ministry of Health in Brazil as having great strategic promise within the area of drugs and medicine. In this regard, this article seeks to present the findings of an exploratory research project investigating the participation of Brazilian universities in the formation of strategic partnerships focused on the development of drugs, after the advent of the Brazilian Innovation Law. An exploratory study was used as an instrument of methodological support, backed by a survey whose results allowed the authors to identify some significant reflections structured in the universitypharmaceutical industry-government approach.
\end{abstract}

Keywords: pharmaceutical industry; innovation; university-industry-government partnership; government innovation policy.

\footnotetext{
'Fluminense Federal University(UFF).Address: Rua Passo da Pátria, I 56 - Sala 329 - Bloco E,Escola de Engenharia-UFF, São Domingos - Niterói - Cep: 24210-240, + 5521 2629-5617, rochamifarma@yahoo.com.br. Coordinator of the Pharmaceutical Industry group at Association of Pharmacists of Rio de Janeiro (AFAERJ).

${ }^{2}$ Fluminense Federal University (UFF).Address: Rua Passo da Pátria, I 56 - Sala 329 - Bloco E, Escola de Engenharia-UFF, São Domingos Niterói - Cep: 24210-240, + 55 2l 2629-5617, gilson@latec.uff.br.Associate Professor at Industrial Department in Federal Fluminense University, Rio de Janeiro, Brazil.

${ }^{3}$ Fluminense Federal University (UFF).Address: Rua Passo da Pátria, I 56 - Sala 329 - Bloco E, Escola de Engenharia-UFF, São Domingos Niterói - Cep: 24210-240, + 552 I 2629-5617, vlameira@uol.com.br. Member of the National Investor Relations Institute in Brazil and member of the Advisory Board of the Association of Investors in Portugal.

${ }^{4}$ Fluminense Federal University (UFF).Address: Rua Passo da Pátria, I 56 - Sala 329 - Bloco E, Escola de Engenharia-UFF, São Domingos Niterói - Cep: 24210-240, + 5521 2629-5617, quelhas@latec.uff.br.Associate professor of Federal Fluminense University (UFF).
} 


\section{Introduction}

For the pharmaceutical industry, innovation is the keyword. Considered to be science-based, innovation is the key source of intra-industrial competitiveness, and it generates significant impacts on the public health of a Country (RADAELLI, 2006), which becomes less dependent on foreign innovations (GREWAL, 2008). In addition, for the pharmaceutical sector, product innovations (such as medications) have much more significant results than technological, marketing or process advances (GREWAL, 2008).

It is only through drug innovation that patients can and do benefit from treatments that were unimaginable some time ago. There are still many diseases whose treatment is not yet perfect, suggesting that there is still much room for drug innovation. Without the efforts of companies and other stakeholders (ex. universities) to pay greater attention to Research and Development (R\&D) in the sector, these benefits would not be possible. (COMMISSION, 2009).

\section{Aspects of Innovation in the Brazilian Pharmaceuti- cal Industry}

Although it ranks 8th in the world medicine market, Brazil has maintained its medication production by importing technology, due to its lack of history in innovation. This context demonstrates a fragile reality in the strategy of technological development, since some knowledge must be developed internally. This is the teaching that international experience has demonstrated and the Country has the potential to share scientific and technological research activities, which have been restricted to the academic environment or governmental institutions, not interacting with the business sector that generates wealth (VIEIRA, 2008).

It is extremely important that the pharmaceutical sector be prioritized by the Government as a strategic option for composing the Industrial, Technological and Foreign Trade Policy (PITCE). Under this policy, the R\&D incentive is one of the foundations to substantiate this sector, which utilizes innovation as a key element for the growth of industrial and domestic competitiveness (SAÚDE, 2008). The willingness to differentiate products, to increment processes efficiency and to enter in new markets, represent the main reasons that have driven companies of the sample to innovate. On the other hand, the main obstacle met by companies during development and introduction of innovation is represented by the difficulties to establish partnership with other companies, by financial problems and lack of resources in the company (BIGLIARDI, 20I I). Additionally, the business environment is not conducive to the research environment and the lack of a culture of innovation, coupled with the pressure to increase the portfolio of new products sacrifices the research, which fails to occur at the rate of production (CUATRECASAS, 2006).

In Brazil, the National Science, Technology, and Innovation Policy, of the Ministry of Health, aims for greater integration between academia and the industrial sector through the "implementation of policies for the development of healthcare production complexes, integrating and strengthening research and technology centers, official laboratories, institutions for higher education, middle school and vocational training, and domestic companies, with emphasis on the research and production of drugs, products, processes and equipment for healthcare" (SAÚDE, 2008).

\section{University-Pharmaceutical Industry Partnership}

A research covering the years from 1993-2003 has shown the pharmaceutical sector has progressed a little - or almost nothing - during this period: the rate of importation was enormous and no public policies were created to foment a significant change or recuperation in the sector (SILVA, 2007). Therefore, given the importance of innovation for the economy, the Innovation Law of 2004 was considered a breakthrough for the Brazilian Government, in the sense that it increases flexibility and the patent rights of the University, in addition to creating Technological Innovation Centers (TICs) in order to monitor the development stages of a project with potential interest for the private sector and facilitate technology transfer from the university to the business sector, for example, through licensing (SBRAGIA, 2006). In universities without the management of TICs, a large number of patent requests is abandoned due to expiration of payments (annuities) terms, while in the universities where research has been developed by means of a structured Technological Innovation Centers, the Index of Patents Granting of the universities showed significant increase (QUERIDO, 20I I).

In the last decade, in the USA alone - which features cooperation between universities and industry for R\&D (SCHWAB, 2010) - more than I,000 partnerships were made between companies and Academia (ELMUTI, 2005). Support for research and development activities and the time to market (TTM) of their results have already been a reality in many countries for many years, either through technology transfer centers linked to research institutions, or partnerships between universities and companies, and support for technological cooperation between companies (AVILA, 2004).

Success stories arising from partnerships between universities and the pharmaceutical industry abroad benefited society in the form of drugs that are widely used today: patents of the anticoagulant Warfarin and Vitamin D (University of Wisconsin); of the antitumor agent Cis-platinum (Michigan 
State University); of the vaccine against the Haemophilus bacteria that causes Meningitis (University of Rochester)

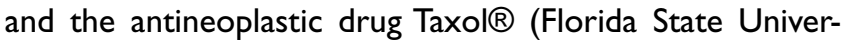
sity) (DEMAIN, 200I). In Brazil, the only exclusively Brazilian drug, the topical anti-inflammatory Acheflan, was created in partnership with four of the Country's major universities (Federal University of Santa Catarina, Unifesp, PUC-Campinas and Unicamp) (ACHÉ, 20I I). Taking into consideration that big pharmas have held the largest amount of technological capacities from the strategic alliances, in particular molecules, it can be understood that their interest in participating in strategic alliances should be a way of reacting at internal and external changes, with the objective of keeping competitiveness in the pharmaceutical market (OHABA, 2007).

With regard to the universities, some authors see this partnership as a possibility to generate technological innovation and intellectual property, contributing to socio-economic progress, while the involvement in a business environment enriches teaching. In addition, there is a real possibility to reduce the companies' spending on Research and Development (R\&D) (SALOMON, 2008). In the biotechnology sector, for example, a study demonstrated lower spending when there is a company-university partnership, or rather, lower spending on R\&D (GEORGE cited in ELMUTI, 2005). Thus, the relationship between universities and companies has been identified as a source for new products and consequently a factor for economic growth (DZISAH, 2008), as well as, through research programs, a method of solving practical business problems (ELMUTI, 2005).

\section{The Problem situation}

In Brazil, even with the Innovation Law, of the 315 companies that manufacture pharma-chemical and pharmaceutical products that implemented innovations, only 18 received governmental support for R\&D through tax incentives, only I4 of which made partnerships with universities (where 61\% used the partnership for R\&D and trials for product testing; the target of the pharmaceutical industries) (IBGE, 20I0).

Paradoxically, the number of patents requested by universities has increased and the healthcare sector is greatly represented (SENNES; MENDES, 2009), which indicates that the universities are looking at the market in a more entrepreneurial manner, even if they are not proactively conducting market studies for technological demands (PEREIRA, 2009). Nevertheless, the university-company interaction is insignificant and still faces many difficulties in its development. For this relationship to be successful, it is especially important that each side have the desire and willpower to make the relationship happen (SENNES, 2009). This is because the universities, for example, use basic research to contribute to the knowledge of new types of concepts, models and em- pirical findings (ELMUTI, 2005). Furthermore, there are still, traditionally, conflicts of interest, culture and objectives with the companies (LEE, 2000).

According to the president of the Association of National Pharmaceutical Laboratories (Alanac), in addition to bureaucratic obstacles, there should be more resources for funding and particularly greater synchronization between the private sector and academia where "many resources are allocated and not returned as products in the market", says Geyer (GOLDBERG, 20I0).

Given that the international community has recognized, for some time, the importance of universities for innovation, this article's main objective is to present the findings of an exploratory study that investigated the participation of Brazilian universities with regard to the formation of strategic partnerships focused on drug development, after the advent of the Brazilian Innovation Law.

\section{Materials and Methods}

The study of the University-Company cooperative process is characterized, with regard to its nature, as descriptive, because it uses both quantitative and qualitative data. The qualitative and quantitative methods are not mutually exclusive. The qualitative approach can be distinguished from the quantitative approach, but it would not be accurate to state that they are related by opposition. Although different in form and emphasis, the qualitative methods contribute to the research work a mixture of procedures that are both rational and intuitive in nature, and capable of contributing to a better understanding of the phenomena.

The research was divided into two phases. The first phase was quantitative in nature, using survey questionnaires to collect data between the months of May and June of $20 \mathrm{II}$. The Universities' Technological Innovation Centers (TICs) were the primary focus of the investigation and the respective respondents.

Although there are known difficulties in obtaining an appropriate quantity of responses to the questionnaire, this method was chosen to provide a basis for answering the research hypothesis, in view of the positivist approach for the objective of this study.

The survey method seems the most appropriate for understanding the behavior of a relatively large population sample. In this phase, in order to analyze the questionnaire data (quantitative stage), the Statistical Package for the Social Sciences (SPSS) program was used. 
In the second phase, in order to include the qualitative elements, content research was conducted by the Technological Innovation Centers (TICs), also created by the aforementioned Law. Content analysis can be defined as an investigative technique intended for the objective, systematic and quantitative description of the manifest content of communication.

\section{Field Research and Analysis}

In order to reach the objectives and answer the research questions, the questionnaire was developed by adapting the proposal presented by Bekkers and Freitas (2008) and Lee (2000) and organized by the author into 5 clusters: (I) institutional profile, (2) strategy, (3) government participation, (4) knowledge/technical capacity and, (5) university as a strategic partner, with the following objectives:

(I) Institutional Profile

Identify the profile of the studies made possible through the TICs and the temporal profile of the TICs after the Innovation Law.Validate the respondent as an active participant of the TIC and identify whether or not they have experience in the private sector:

\section{(2) Strategy}

Measure how much time is dedicated to the applied research and how much the research made possible through the TICs is driven by the market; identify the companies' profiles with regard to licensing options provided by the Innovation Law, from the perspective of the University.

\section{(3) Government Participation}

Measure the University's perception with regard to the government's involvement and promotion of medicines and the Government's participation as a funder; identify gaps in government action in encouraging drug innovation by the Pharmaceutical Industries, from the universities' perspective: (4) Knowledge/Technical Capacity:

Identify if the studies made possible through the TICs are often patented prior to publication in scientific journals; identify the Universities' perception with regard to knowledge transfer to businesses; identify the Universities' perception with regard to their technical preparation in order to meet the requirements of the pharmaceutical companies in the stages of new drug development:

\section{(5) University as a Strategic Partner}

Measure the TIC's perception with regard to their own professional profile and enabler of partnerships with businesses; identify if the universities formed partnerships for new drug research, after publication of the Innovation Law:

\section{Validation and data collection}

The pilot questionnaire was pre-tested with 5 (five) professionals ( 2 professors and 3 Masters students/PhD students) with both academic/research and academic/market experience. After analyzing the pilot pre-test, minor alterations in form, composition and organization were made, and then the final questionnaire was made available electronically on the Internet through research software.

Thus, as an auxiliary tool used to collect data, the software SurveyMonkey@ (www.surveymonkey.com) was employed, which allows responses to be sent and received via the Internet, enabling the participation of professional specialists. The questionnaire was available on the Internet between the months of May and June of 20II and was mainly composed of open and closed questions, in order to facilitate the collection and interpretation of data.

Thus, it included mandatory questions, multiple choice, semiopen, dichotomous questions (Yes/No) and opinion gradation using the Likert scale. Some open questions were used with the objective of obtaining "supplementary information" in case the respondent wishes to express an opinion relevant to the topic. Following the Mattar guidelines (1996), identification of the respondents was requested only at the end of the questionnaire so that there is no risk of distorting the responses in the event that personal data was already provided at the beginning of the research.

We sought to define a set of questions that required no longer than 15 minutes from the respondent, and used logical question sequencing, in order to direct the respondent based on the responses previously provided.

The 25 Technological Innovation Centers listed on the Ministry of Development, Industry and Foreign Trade website (www.mdic.gov.br) were considered and all of these TICs were contacted via E-mail.

\section{Discussion and Analysis of Results}

\section{Field profile and analysis}

Fifty six percent (56\%) of the Technological Innovation Centers (TICs) responded to the research, a large majority of which were created after the Innovation Law (93\%).

Of the TICs' respondents, $66.7 \%$ have already worked and experienced the modus-operandi of a private institution and have worked in the TIC for more than 2 years, at least, and include: directors $(8 \%)$, coordinators $(33 \%)$, administrators $(8 \%)$, professors (17\%) and innovation agents ( $8 \%)$.

ISSN: 07 I8-2724. (http://www.jotmi.org)

Journal of Technology Management \& Innovation (C) Universidad Alberto Hurtado, Facultad de Economía y Negocios. 
Thus, the profile demonstrates that the participation and involvement of the respondents tends to be active in the TICs, which was favorable to the study objective.

Research in the area of pharmaceuticals, which is important for new drug development and the purpose of this work, was identified as one of the areas that most represents the research that reaches the TICs (27\%).

\section{Strategy}

Compared to basic research, applied research was identified as having a greater frequency with regard to the type of research that characterizes the responding TICs:
This finding provides further perspective on the Elmuti (2005) study, since he states that the Universities develop only basic research, not applicable to the market. However, this finding could result from a bias, since the research that reaches the TICs (which are not all of the studies developed within universities) already arrived with the purpose of being licensed for the market; a result of the entrepreneurial vision of the researcher.

Based on this information and the data presented in Figures 4 and 5 , the responding TICs feature applied research and many of them cover the pharmaceutical sector, which can be fertile ground for attracting the interest of pharmaceutical companies interested in innovation.

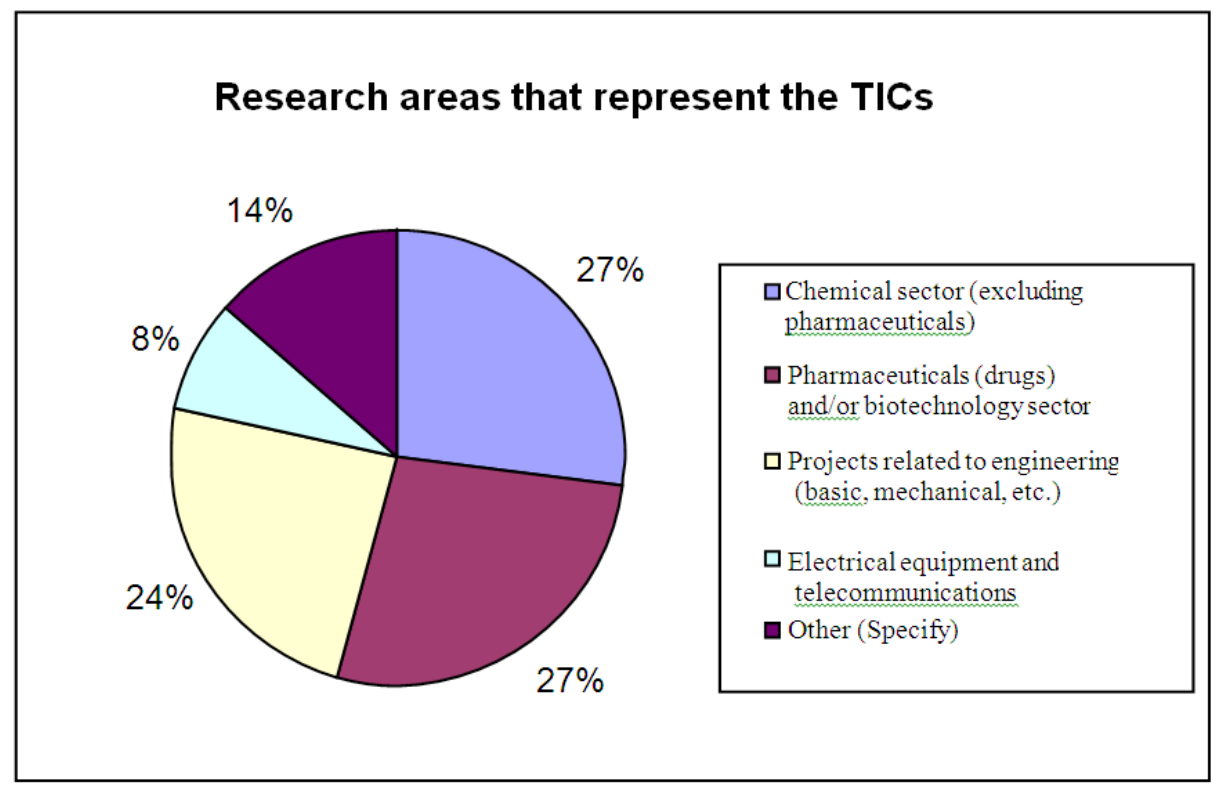

Figure I: Research areas that represent the TICs. Source:The authors (20II)

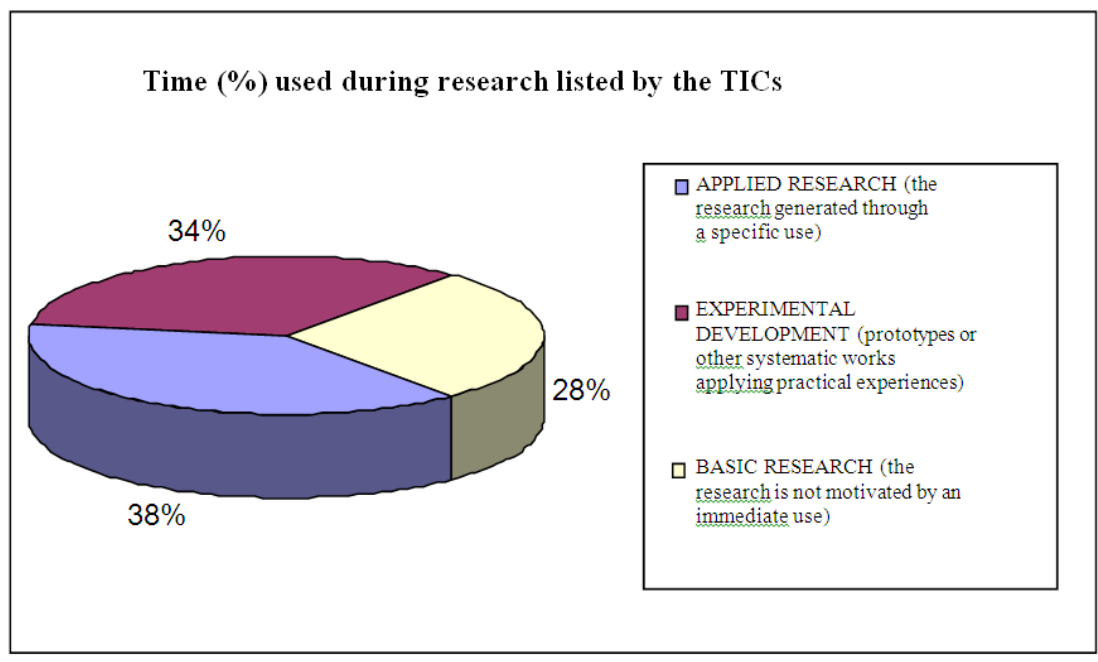

Figure 2: Universities: applied research $\mathrm{x}$ basic research. Source:The authors (20II)

ISSN: 07 I8-2724. (http://www.jotmi.org)

Journal of Technology Management \& Innovation (C) Universidad Alberto Hurtado, Facultad de Economía y Negocios. 
However, with regard to the guidelines for researching new drugs, the TICs demonstrate divergent and unfocused opinions:

In other words, there is not a consensus between the TICs regarding the factor that guides new drug research (if it is the government or the market). Other opinions mentioned were: "society's demand", “public universities", "I don't know", "depends on the source of funds, could be the government or the market", "by the needs verified by the gaps". This demonstrates that, if it is not the source of funds, as one respondent points out, the universities are strategically not in line with the therapeutic needs of the market, nor the expectations of the Government's public policies, which include drugs for neglected diseases. This disconnect is corroborated by what was presented by Pereira (2009), where a lack of market research performed by the University is a reality. Thus, even with a growing number of patent requests made by universities, as shown by Sennes (2009), the research cannot meet the expectations of the market.

\section{Government participation}

According to the results below, the responding TICs are primarily funded by the Government.

However, there is not a consensus as to whether or not the Government is a facilitator for universities with regard to their encouragement of new drug research, given that the total number of respondents that believe the Government is a supporter equals the number of respondents that described it as "indifferent" or "somewhat active".

This information also indicates that there is a disconnect between the Government and universities for developing innovative drugs, which should be worked on to provide a favorable environment for innovation in this sector. If the Innovation Law is viewed by the Ministry of Health (2008) as a great promise "whereby we hope to open a fruitful channel of collaboration between businesses and academic research institutions", it is necessary to effectively direct the universities towards this objective.

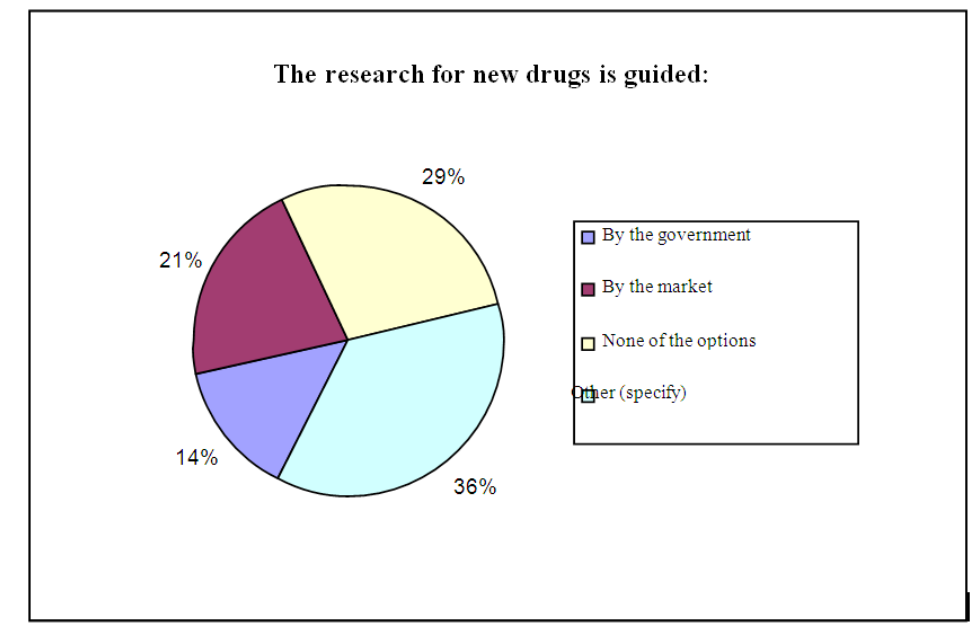

Figure 3: Guidelines for drug research - viewpoint of the universities. Source:The authors (20II)

\begin{tabular}{|l|c|c|c|c|c|}
\hline \multicolumn{6}{|c|}{ Indicate approximately how much (in \%) your university's TIC was funded in the last 6 years: } \\
\hline Responses & $\begin{array}{c}\text { Almost none } \\
\mathbf{0 - 2 5 \%}\end{array}$ & $\begin{array}{c}\text { Sporadically } \\
\mathbf{2 6 - 5 0 \%}\end{array}$ & $\begin{array}{c}\text { Frequently } \\
\mathbf{5 1 - 7 5 \%}\end{array}$ & $\begin{array}{c}\text { Always } \\
\mathbf{7 5 - 1 0 0 \%}\end{array}$ & $\begin{array}{c}\text { Likert } \\
\text { Scale }\end{array}$ \\
\hline $\begin{array}{l}\text { Direct funding from the } \\
\text { government }\end{array}$ & 3 & 3 & 3 & 3 & $\mathbf{2 . 5 0}$ \\
\hline $\begin{array}{l}\text { Indirect funding from the } \\
\text { government }\end{array}$ & 8 & 1 & 2 & 1 & 1.67 \\
\hline $\begin{array}{l}\text { Commercial funding (financing } \\
\text { agreement) }\end{array}$ & 11 & 1 & 0 & 0 & 1.08 \\
\hline $\begin{array}{l}\text { Private, non-profit research } \\
\text { foundations }\end{array}$ & 8 & 2 & 0 & 2 & 1.67 \\
\hline
\end{tabular}

Table I:TIC Funding. Source:The authors (201I)

ISSN: 07 I8-2724. (http://www.jotmi.org)

Journal of Technology Management \& Innovation (C) Universidad Alberto Hurtado, Facultad de Economía y Negocios. 


\begin{tabular}{|l|c|}
\hline \multicolumn{2}{|l|}{ How much does your TIC observe government incentives for new drug } \\
innovation with the universities? \\
\hline Responses & $\%$ responses \\
\hline Very active & $0.0 \%$ \\
\hline Active & $50.0 \%$ \\
\hline Indifferent & $\mathbf{8 . 3 \%}$ \\
\hline Slightly Active & $\mathbf{4 1 . 7 \%}$ \\
\hline Irrelevant & $0.0 \%$ \\
\hline
\end{tabular}

Table 2: Government incentive - Universities' perspective. The authors (20II)

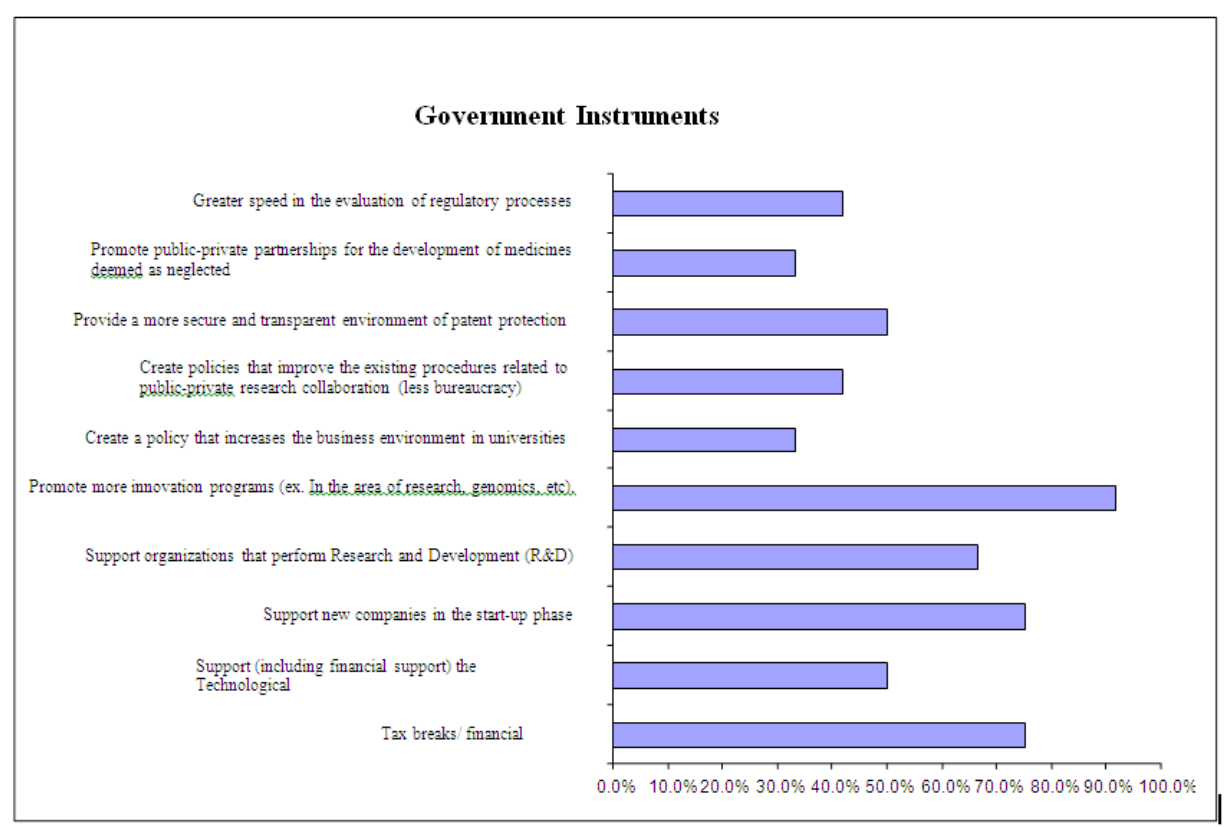

Figure 4: Instruments for the government to promote drug innovation. Source:The authors (20II)

As previously noted, the universities seem to not understand the role that they should play in this context, since they are not aligned with the companies or the public health policies (Figure 6). Given the strong influence of the government, primarily in the public universities, it is necessary that this link with the companies occurs through governmental policies focused on this purpose.

In order to identify shortcomings in government actions, several factors were identified by the Universities as important for the real incentive of drug innovation.

For the TICs, the best instruments for the government to increase and improve the research for drug innovation is to promote more innovation programs and more companies in the start-up phase, as well as provide tax breaks/ financial support.

Universities also believe that the government should better support the organizations that perform R\&D, instead of emphasizing the need to create a more entrepreneurial environment in academia and promoting partnerships with companies in order to develop orphan drugs.

\section{Knowledge / Technical Capacity}

According to the TICs, the Universities mainly expressed their knowledge through scientific documents, such as articles, publications in journals and lectures (4.00 on the Likert scale) as opposed to "grey literature", such as patents (3.14 on the Likert scale), even though some studies are available for licensing by the companies.

From the TICs' perspective, there are still significant barriers for knowledge transfer from the universities to the industry, which ends up using a very small amount of the knowledge available in universities. This is because it is difficult to overcome culture factors between universities and the company's commercial interests, since many partnerships are hindered by conflicts between Academia seeking to publish

ISSN: 07I 8-2724. (http://www.jotmi.org) 
the results and the company, which wants to patent the research. Nevertheless, as discussed by Demain (200I), such sources of conflict can be bypassed in order to ensure the alliance's success if the inventions have their patent application filed immediately so that the study can then be made available to the scientific community.

However, the universities realize that conducting this type of contract brings income to the university and disagree that this type of partnership cannot contribute to the development of research and that the industry will not be interested in the knowledge developed in the university.

Universities recognize that there is not incentive for cooperating with the industry, since the results are measured through scientific publications. With regard to the promotion of drug innovation, this could be an issue to be tackled by the Government, which localizes its resources to prioritize publications instead of aligning the applicability of the research to the needs of the market or the society.

This finding shows that the TICs' vision is optimistic with regard to partnerships with pharmaceutical companies, but it still needs better structural support to allow for a more entrepreneurial profile and, consequently, the implementation of more partnerships between universities and companies in favor of new drugs.

As for technical preparations for meeting the pharmaceutical market's needs, see the graph below, where it appears

Please indicate if you agree with the following statements in relation to the TICs and the companies:

\begin{tabular}{|c|c|c|c|c|c|c|}
\hline Responses & $\begin{array}{l}\text { Completely } \\
\text { disagree }\end{array}$ & $\begin{array}{l}\text { Somewhat } \\
\text { disagree }\end{array}$ & $\begin{array}{l}\text { Neither } \\
\text { agree nor } \\
\text { disagree }\end{array}$ & $\begin{array}{l}\text { Somewhat } \\
\text { agree }\end{array}$ & $\begin{array}{l}\text { Completely } \\
\text { agree }\end{array}$ & $\begin{array}{l}\text { Likert } \\
\text { Scale }\end{array}$ \\
\hline $\begin{array}{l}\text { There are still significant barriers for knowledge } \\
\text { transfer from universities to the industry }\end{array}$ & 0 & 1 & 0 & 6 & 5 & 4.25 \\
\hline $\begin{array}{l}\text { Private companies make very little use of the } \\
\text { knowledge available in universities }\end{array}$ & 1 & 2 & 0 & 7 & 2 & 3.58 \\
\hline $\begin{array}{l}\text { Cooperation with the industry is hindered by } \\
\text { cultural factors, or rather, differences between } \\
\text { Academia and commercial interests }\end{array}$ & 1 & 3 & 1 & 3 & 4 & 3.50 \\
\hline $\begin{array}{l}\text { Many partnerships are hindered by conflicts } \\
\text { between Academia, which seeks to publish the } \\
\text { results and the company, which wants to patent } \\
\text { the research }\end{array}$ & 1 & 2 & 1 & 6 & 2 & 3.50 \\
\hline $\begin{array}{l}\text { There is no incentive to cooperate with the } \\
\text { industry; the university's results are measured } \\
\text { through scientific publications }\end{array}$ & 1 & 3 & 1 & 4 & 3 & 3.42 \\
\hline $\begin{array}{l}\text { It is difficult to find partners in the private } \\
\text { industry for R\&D partnerships }\end{array}$ & 0 & 6 & 1 & 3 & 2 & 3.08 \\
\hline $\begin{array}{l}\text { Companies do not want to cooperate with R\&D } \\
\text { in the universities; they only want to absorb our } \\
\text { knowledge }\end{array}$ & 2 & 4 & 1 & 5 & 0 & 2.75 \\
\hline $\begin{array}{l}\text { Transferring knowing to the industry is very } \\
\text { costly for the universities (in terms of time and } \\
\text { money) }\end{array}$ & 4 & 5 & 1 & 1 & 1 & 2.17 \\
\hline $\begin{array}{l}\text { The industry is not interested in the knowledge } \\
\text { developed in the universities }\end{array}$ & 6 & 5 & 0 & 1 & 0 & 1.67 \\
\hline $\begin{array}{l}\text { The knowledge flows from the industries to the } \\
\text { universities }\end{array}$ & 7 & 3 & 1 & 1 & 0 & 1.67 \\
\hline $\begin{array}{l}\text { The universities are not willing to spend time and } \\
\text { money transferring their knowledge to industries }\end{array}$ & 8 & 3 & 0 & 0 & 1 & 1.58 \\
\hline $\begin{array}{l}\text { Conducting research contracts with companies } \\
\text { brings income to the university, but this type of } \\
\text { research does not contribute to the development } \\
\text { of research }\end{array}$ & 10 & 1 & 0 & 1 & 0 & 1.33 \\
\hline
\end{tabular}

Table 3: Knowledge transfer with companies - universities' perception Source:The authors (20I I)

ISSN: 07 I8-2724. (http://www.jotmi.org)

Journal of Technology Management \& Innovation (c) Universidad Alberto Hurtado, Facultad de Economía y Negocios. 


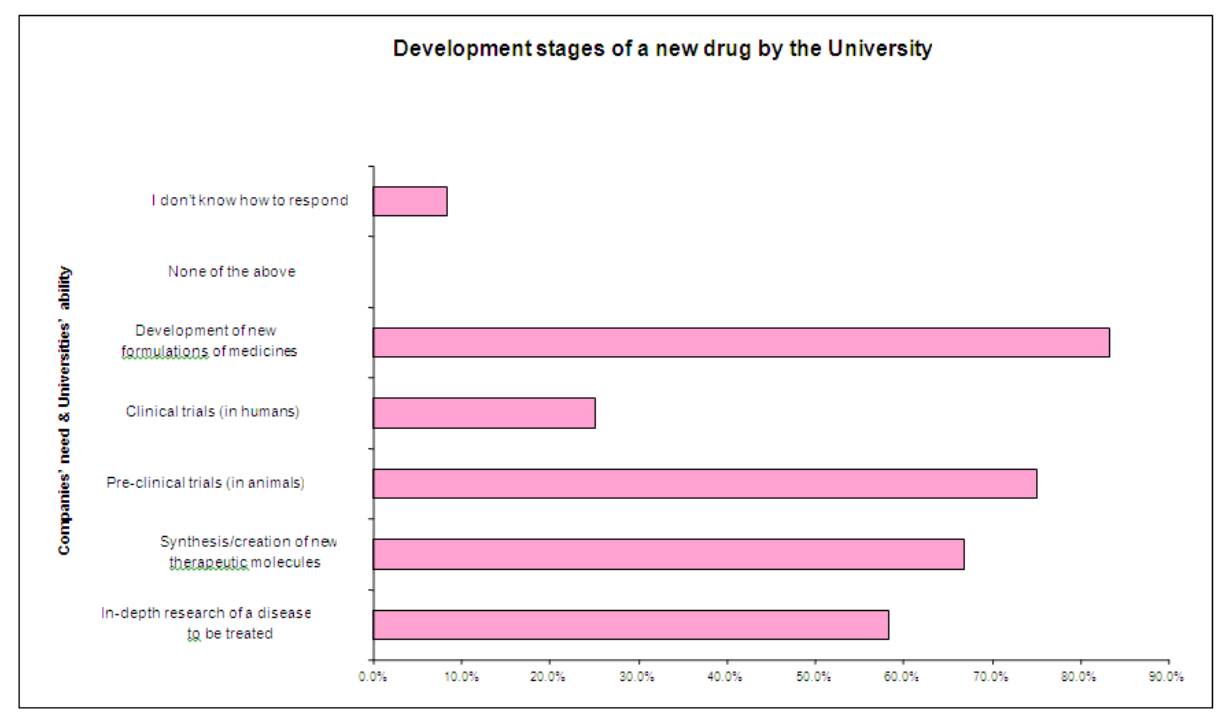

Figure 5: Development of new drugs - universities' technical capacity. Source:The authors (20II)

that almost all of the companies' strategic needs can be met by the Universities.

Thus, from the perspective of the TICs, for the development of new drugs, the University is capable of conducting, primarily, research for the development of new formulations of medicines, pre-clinical trials (in animals), followed by synthesis/creation of new therapeutic molecules, in addition to in-depth research of diseases to be treated, in this order.

\section{The University as a strategic partner}

From the viewpoint of the Universities, in the past 6 years, partnerships for new drug R\&D did not occur very often with private companies, which is confirmed by the IBGE (2010) data.

In order to identify the perception of the University itself, through the TICs, with regard to its preparation for meeting the needs of the pharmaceutical market, the graph below shows that the universities believe they advertise their services and they are easily accessible. They also believe that their physical resources are relevant and they have access to researchers with highly qualified "know-how" and the expertise and reputation to develop research and meet the companies' expectations, which can paint a better picture for the companies and reduce costs and/or risks.

However, the universities, through the TICs, disagree that they cannot guarantee confidentiality/patent protection, that they are slow or bureaucratic, that they have long-term, non-feasible projects, and that they are unpredictable or lacking professionalism.
Thus, the results of this study show that although most of the studies that reach the TICs to be licensed are in the pharmaceutical area and are based on applied research, partnerships with private companies after the Innovation Law were poorly represented. While the representatives of the TICs believe that the universities feature the technical ability and knowledge to contribute to any stage of new drug development, there is no guidance for this type of research since it lacks cooperative involvement between the universities, the needs of market and the government's healthcare policies. The data also showed that the TICs believe that partnerships with the private sector still present difficulties, but they can bring new experiences and income to Academia, whose government incentive for drug research and development, which can bring practical improvements to healthcare and quality of life, is still unsubstantial.

\section{Conclusions}

This study resembles, in a general way, the Brazilian empirical studies that discuss the partnership between universities and companies, aiming to contribute, in a more specific way, to the sectoral study of the Brazilian pharmaceutical industry, one of the priorities of innovation in the Country. This research shows that the TICs formed few partnerships/licensing with private drug companies after the Innovation Law and still believe there to be strong barriers with the private sector, despite real cases of success achieved in the market; the objective of this partnership.A more direct support is needed for the TICs, which should have greater autonomy and participation with the University, such as the American offices of technology transfer that actively seek technology developed by the universities to bring to the market, raising funds for the development of further research within the university. 


\begin{tabular}{|l|c|c|c|c|c|}
\hline \multicolumn{1}{|l|}{ In the last 6 years, indicate the frequency with which your university's TIC formed a partnership for drug } \\
\hline Responses & Never & Occasionally & Frequently & Always & Likert Scale \\
\hline $\begin{array}{l}\text { Other Universities or higher education } \\
\text { institutions }\end{array}$ & 2 & 5 & 3 & 2 & $\mathbf{2 . 4 2}$ \\
\hline $\begin{array}{l}\text { Governmental institutions or private non- } \\
\text { profit research institutions }\end{array}$ & 3 & 6 & 2 & 1 & $\mathbf{2 . 0 8}$ \\
\hline Private companies & 3 & 6 & 2 & 1 & $\mathbf{2 . 0 8}$ \\
\hline Other departments within the university & 5 & 4 & 2 & 1 & $\mathbf{1 . 9 2}$ \\
\hline $\begin{array}{l}\text { Commercial manufacturer or service providers } \\
\text { (except consultants) }\end{array}$ & 7 & 3 & 1 & 1 & $\mathbf{1 . 6 7}$ \\
\hline \\
Did not form a partnership in this area
\end{tabular}

Table 4: Frequency of TIC partnerships for drug R\&D.

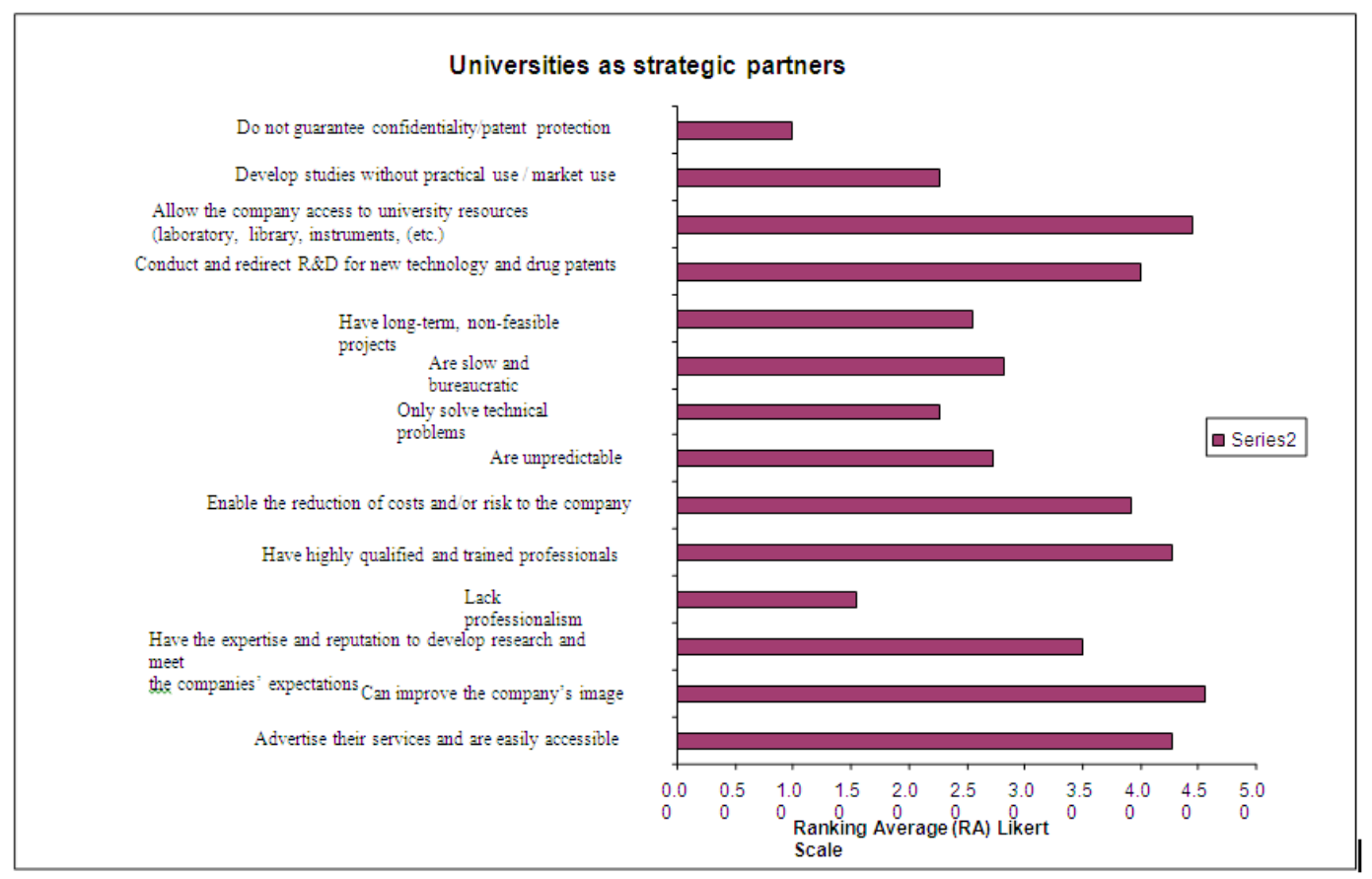

Table 4: Frequency of TIC partnerships for drug R\&D.Figure 6: Universities as strategic partners

Government still needs to encourage a new way of measuring Academia's results and be more assertive in relation to the goals and drug innovation programs within the universities, where the results are still (mostly) measured through scientific publications and where many studies are developed (and sometimes patented), but did not arouse the interest of any stakeholders.
The TICs, in turn, seem to not know the real market demands or the demands of the public healthcare system, including with regard to neglected diseases. It is therefore necessary that the Universities become part of the Triple Helix model and become more active in this context, seeking closer ties with the Government and the market needs, demanding a paradigm shift, including changes in procedures

ISSN: 07 I8-2724. (http://www.jotmi.org)

Journal of Technology Management \& Innovation (C) Universidad Alberto Hurtado, Facultad de Economía y Negocios. 
and standards that are hindering this interaction and, consequently, innovation.

It is true that educational institutions should not be dictated by market or commercial objectives, as believed by Cuatrecasas (2006), but the applied studies should, realistically, be more relevant within society. The TICs, acting through offices linked to the University, have a professional structure that most closely matches the requirements of the pharmaceutical market and they can be important propagators of the technical capacity of their universities and their ability to add to the Brazilian economy and to companies through the development of drugs.

Although they require greater support from the government, the universities must overcome the barriers to achieve partnerships, developing abilities that result in greater expressivity of entrepreneurial interactions.

It is therefore important that the TICs make available their abilities, services and studies for licensing in a channel that is closely related to and accessible by the pharmaceutical market. Within the institutions and the University, the TICs can and should be an important channel for disseminating entrepreneurship within Academia, in addition to further advertising the Innovation Law itself.

Thus, there is fertile ground for Universities as viable strategic partners, given that, from the point of view of the TICs, this type of partnership enriches research and attracts investment for the University.

Nearly 7 years since the Innovation Law's enactment, it is necessary to change the view of Stal (2006), who claimed that the universities do not have a tradition of forming relationships with companies and do not bother to communicate research findings with the private sector, so as to contribute to the production of innovations.

Our country is dying for innovations, while traditionally the doctors remain in universities, because there is no closeness with Academia. In Brazil, the only genuinely Brazilian drug has so far been developed with the help of Brazilian Universities and this is an indication that this type of partnership could also work here.

Therefore, the research met the proposed objectives and, inferring from this study, investigations that seek a more indepth, descriptive approach, or even the viewpoint of the pharmaceutical companies in this type of partnership, could generate new findings.

\section{References}

ACHÉ. (20I I). Acheflan ${ }^{\circledR}$ Aerosol: da natureza vem o mais novo tratamento para traumas esportivos. http://www.ache. com.br/PressRoom/News.aspx?Newsld=156 [Accessed June II, 20II]

BEKKERS, R. e Bodas Freitas, I. M. (2008) Analyzing knowledge transfer channels between universities and industry:To what degree do sectors also matter? Research Policy, v.37, n. 10, p. $1837-1853$.

BIGLIARDI, B., COLACINO, P., et al. (20II) Innovative characteristics of small and medium enterprises. Journal of Technology Management \& Innovation, v.6, issue 2, p.83-93. 201 I.

BRAZIL. (200I). Provisionary Measure no. 2.190-34 of 23 August 200I. Changes the provisions of Laws no. 9.782, of 26 January 1999, which defines the National System of Sanitary Surveillance and creates the National Agency of Sanitary Surveillance, and no. 6.437 of 20 August 1977, which configures violations of federal sanitary legislation and establishes the respective sanctions, and provides additional provisions. Official Gazette, Presidency of the Republic, Staff, Chief Deputy of Legal Affairs, Brasilia. Section I

COMPETITION, E. C. (20I0). Pharmaceuticals and public health in the EU: Proposals to the high level committee on health for policies and actions in the framework of the treaty of Amsterdam. 28 March 2000. http://ec.europa.eu/competition/consultations/2009_pharma/index.html [Accessed September 12, 2010]

CONDE, M.V. F. e Araújo-Jorge, T. C. (2003). Modelos e concepções de inovação: a transição de paradigmas, a reforma da C\&T brasileira e as concepções de gestores de uma instituição pública de pesquisa em saúde. Cien Saude Colet, v.8, n.3, p.727-74I.

CUATRECASAS, P. (2006). Drug discovery in jeopardy. Journal of Clinical Investigation, v. I I6, n. I I, p.2837-2842.

DEMAIN, A. L. (200I). The relationship between universities and industry: the American university perspective. Food Technology and Biotechnology, v.39, n.3, p.157-160.

DZISAH, J. e Etzkowitz, H. (2008). Triple helix circulation: the heart of innovation and development. International journal of Technology Management and Sustainable Development, v.7, n.2, p.101-II5.

ELMUTI, D.,Abebe, M., et al. (2005).An overview of strategic alliances between universities and corporations. Journal of Workplace Learning, v. 17, n. I/2, p.I I5-129.

ISSN: 07I 8-2724. (http://www.jotmi.org)

Journal of Technology Management \& Innovation (c) Universidad Alberto Hurtado, Facultad de Economía y Negocios. 
GOLDBERG, S. SUS economiza com fabricação de 22 produtos no país. http://www.sincofarma.org.br/noticias/noticiasdescricao.asp? Textos_ID = | 4058 [Accessed November I2, 20I0].

GREWAL, R., Chakravarty, A., et al. (2008). Counting chickens before the eggs hatch: Associating new product development portfolios with shareholder expectations in the pharmaceutical sector. International Journal of Research in Marketing, v.25, n.4, p.26I-272.

IBGE. (20I0) Pesquisa de Inovação Tecnológica 2008. 2010. http://www.pintec.ibge.gov.br/index.php?option $=c_{-}$ content\&view $=$ article\&id=56:ibge- divulga-os-resultados-dapintec-2008\&catid $=7$ :noticias\&ltemid $=10$ [Accessed January, 20II]

KUNZ, I. (2003). Relação Universidade-Empresa: uma análise a partir da interação Unicamp-empresas no período 1996200I. (Masters). Dissertation, UNICAMP, são Paulo.

LEE, Y. S. (2000). The sustainability of university-industry research collaboration: an empirical assessment. The Journal of Technology Transfer, v.25, n.2, p.I I I-I33.

MARTIN, B. R. e Etzkowitz, H. (2000). The origin and evolution of the university species. Paper presented at the Organisation of Mode.

MATTAR, F. N. (1996). Pesquisa de marketing.Atlas Publisher, São Paulo, SP

OHBA, M. Collaborating to compete: a search into capabilities and strategic alliances in the pharmaceutical industry. Journal of Technology Management \& Innovation, v.2, issue 2, p. 18-30. 2007.

PEREIRA, V. (2009). Cooperação universidade empresa: estudo dos impactos da lei de inovação sobre a parceria Petrobrás-UFRJ. Niterói. 2009. 37 f. Final Project. (Expert level). Post Graduate in Planning, Construction and Assembly Work at the Fluminense Federal University, Niterói.

QUERIDO, A.L.S., LAGE, C.L.S., VASCONCELLOS, A.G. What is the destiny of patents of Brazilian Universities? Journal of Technology Management \& Innovation, v.6, issue I, p.46-57.20II.

RADAELLI,V. (2006). A Inovação na Indústria Farmacêutica: forças centrípetas e forças centrífugas no processo de internacionalização. Campinas, 2006. 176 f. Dissertation (Masters in Political Science and Technology). Institute of Geosciences, State University of Campinas, Campinas, SP.
ROCHA, M. de M. (20II).Avaliação da parceria entre indústria farmacêutica e universidade como estratégia competitiva para a inovação de medicamentos no Brasil. Niterói, 182 f. Dissertations (Masters in Production Engineering). Fluminense Federal University, Niterói, RJ.

SALOMON, M. F. B. (2008). A política de patentes na relação empresa- universidade: o caso Cristália. Itajubá. 77 f. Dissertation (Masters in Production Engineering). Production Engineering, Federal University of Itajubá, Itajubá.

SANTORO, M. D. (2000). Success breeds success: The linkage between relationship intensity and tangible outcomes in industry-university collaborative ventures. The Journal of High Technology Management Research, v.I I, n.2, p.255-273.

SAÚDE, M. D. (2008). Política Nacional de Ciência, Tecnologia e Inovação em Saúde. Brasília- DF: Secretaria de Ciência Tecnologia e Insumos Estratégicos Departamento de Ciência e Tecnologia. Ministério da Saúde. 2a edição.

SBRAGIA, R., Andreassi, T., et al. (2006). Inovação: como vencer esse desafio empresarial. Clio Publisher, São Paulo.

SEGATTO, A. P. (1996). Análise do processo de cooperação tecnológica universidade-empresa: um estudo exploratório. Dissertation (Masters in Administration). College of Economics, Administration and Accounting, University of São Paulo. SP.

STAL, E. e Fujino,A. (2006). As relações universidade-empresa no Brasil sob a ótica da Lei de Inovação. Revista de Administração e Inovação, v.2, n. I, p.5-19.

SCHUMPETER, J.A. (1947). The creative response in economic history. The Journal of Economic History, v.7, n.2, p. $149-159$.

SCHWAB, K. e Salai-I-Martin, X. (2010). The Global Competitiveness Report 2010-201 I:World Economic Forum.

SENNES, R., Mendes, R. C., et al. (2009) Propriedade Intelectual e Inovação: Uma Análise das Principais Empresas e Universidades Brasileiras. Prospectiva Consultoria.

SILVA, C.L., OLIVEIRA, A. J. Brazilian industry policy after 1990: focusing on the pharmaceutical industry. Journal of Technology Management \& Innovation, v.2, issue 3, p. 7I-84. 2007.

VIEIRA,V. M. M. e Ohayon, P. (2008). Inovação em fármacos e medicamentos: estado-da-arte no Brasil e políticas de P\&D. Revista Economia \& Gestão, v.6, n. 13. 
J.Technol. Manag. Innov. 2012,Volume 7, Issue 3

ISSN: 07I8-2724. (http://www.jotmi.org)

Journal of Technology Management \& Innovation @ Universidad Alberto Hurtado, Facultad de Economía y Negocios. 